\title{
PENANAMAN DAN PENGUATAN NILAI-NILAI KEISLAMAN MELALUI PERAYAAN HARI BESAR ISLAM
}

\author{
Eddy Saputra, Achmad Muhajir \\ Universitas Indraprasta (UNINDRA) PGRI Jakarta \\ Email: saputra2578@gmail.com, achmadmuhajir981@yahoo.co.id
}

\begin{abstract}
Islam in indonesia develops very rapidly. Culture a to make infrastructure islamic teachings if received by the easy.Islamic can survive through tradition peringantan one a day developed by the clergy not before.Can be can be made by media refreshment in improving in values of islamic teachings, knowledge of islamic unmannerly value reflected in to in implementasikan in daily life.Perayaran a day is the concept to non formal education islamic values.The research uses the qualitative method.Technique data collection is in some literasi pertaining research and literature.Achieved results a day on a research that islamic faith and strengthening capable of increase faith and increase tolerance among the people someone religion.
\end{abstract}

Keywords: Strengthening Planting, Value of Islamic, a Day Islamic.

\begin{abstract}
Abstrak
Islam di Indonesia berkembang sangat pesat. Budaya yang menjadi infrastruktur dalam menyampaikan ajaran Islam membuat Islam dengan mudah diterima oleh masyarakat. Islam dapat bertahan salah satunya melalui tradisi peringantan hari besar Islam yang dikembangkan oleh para ulama terdahulu. Ini bisa dapat dijadikan media penyegaran dalam meningkatan nilai-nilai yang pokok dalam ajaran Islam, pemahaman terhadap nilai islam tercermin pada prilaku yang harus di implementasikan dalam kehidupan sehari-hari. Perayaran hari besar merupakan konsep pendidikan non formal dalam menyampaikan nilai-nilai Islam. Penelitian menggunakan metode kualitatif. Teknik pengumpulan data bersumber pada beberapa literasi dan pustaka yang berkaitan penelitian. Hasil yang dicapai berdasarkan metode penelitian bahwa Hari besar Islam mampu menambah keimanan dan penguatan keimanan seseorang dan menambah Toleransi antar sesama umat beragama.
\end{abstract}

Kata Kunci: Penanaman Penguatan, Nilai ke-Islaman, Hari Besar Islam

\section{A. Pendahuluan}

Islam merupakan agama rahmatan lil'alamin tujuan agama tersebut diturunkan untuk memperbaiki akhlak manusia melalui nilainilai yang terkandung didalamnya. Ajaran Islam di ajarkan melalui berbagai lembaga pendidikan, ada yang formal ada juga yang non formal. Pendidikan formal bisa melalui sekolah, kampus, sampai pusat 
kajian sementara yang non formal bisa melalui pesanteran atau pendidikan berbasis masjid. Inti dari semua itu adalah untuk menanamkan dan menguatkan pemahaman tentang Islam.

Masih banyak anggapan bahwa masjid hanya sebatas tempat untuk beribadah dalam arti yang sempit, seperti sholat, padahal masjid dapat lebih dikembangkan menjadi madrasah, lembaga konsultasi hukum, maupun kehidupan sosial yang lainnya.

Segala kegiatan yang ada di masjid harus berimplikasi pada penanaman dan penguatan terhadap nilai-nilai keislaman. Diatara beberapa kegiatan dimasjid salah satunya adalah dengan mengadakan peringatan hari besar keisalaman. Kegiatan tersebut tidak hanya dapat dilakukan dimasjid, sering juga diadakan di sekolah dan tanah lapang. Proses edukasi melaui perayaran hari besar islam tidak mengenal batasan usia dan golongan sehingga sangat efektif untuk menyampaikan nilai-nilai islam ke semua lapisan masyarakat.

Penanaman dan penguatan nilai islam memang harus dilakukan sejak dini. Berangkat dari lingkungan yang paling dekat yakni dimulai dari keluarga lalu kehidupan sekitar. Pondasi terhadap nilai-nilai keislaman harus di perkokoh dalam rangka pembentukan akhlakul karimah, karena sejatinya islam bukan dilihat dari tampilan akan tetapi lebih mengedepankan sikap kita terhadap kehidupan bersosial. Kegiatan penanaman dan penyuluhan agama Islam telah diselenggarakan secara rutin dan terjadwal. Peringatan hari besar Islam adalah sebuah peringtan yang tidak asing lagi, baik dalam kehidupan masyarakat dan bernegara. Negara telah memfasilitasi pelaksaan kegiatan tersebut dengan peringatan hari besar Islam sebagai hari libur nasional.

Soyogyanya peringatan hari besar Islam dapat meningkatkan kualitas terhadap nilai-nilai ke islaman ditengah kurang gairahnya masyarakat muslim dalam menempuh pendidikan formal kegamaan. Ini juga ditandai dengan berkurangnya minat geberasi muda untuk masuk ke lembaga-lembaga pendidikan berbasis Islam. Kampus-kampus Islam yang memiliki program studi Islampun sedikit tertatih-tatih dalam menjaring mahasiswa. Seperti universitas Islam negeri banyak mahasiswanya yang memilih program studi non agama dibanding berbasis agama. Oleh karenanya Model pendidikan non formal ini dapat menembus semua kalangan tanpa terkecuali. Tua, muda, miskin, kaya dan sebaginya.

Kegiatan ini bisa menjadi program singkat dalam mengenalkan sekaligus memupuk nilai-nilai keIslman kepada masyarakat. Materi 
yang disampaikan umumnya dalam bentuk monolog. kemasan yang sederhanya pemyampain materipun dalam bentuk ceramah, apalagi terkadang diselingi dengan guyon membuat semua orang merasa nyaman dan tidak merasa di gurui. Orang yang belum tau menjadi tau esensi dari niali-nilai keIslaman, sementara yang sudah tau dapat mengingatkan kembali agar dapat secara konsisten melaksakan nilai tersebut.

Peringatan hari besar Islam adalah kegiatan memperingati hari besar Islam dengan maksud dan tujuan untuk syiar islam serta mengagali arti dan makna yang pernah terjadi. Penenananman imana hanya sedikit yang di dapat melalui pengajaran, perlu ada usaha melelui selain pengajaran. Yang paling besar pengaruhnya diantara sekian usaha ituialah pendidikan keimanan yang dilakukan oleh orang tua di rumah tangga.berbagai kegiatan yang memiliki dampak positif terhadap penanaman keimanan, kegiatan yang dimaksud adalah melalui acara perayaan hari besar Islam (PHBI).

\section{Nama-nama hari besar Islam}

Nama-nama hari besar Islam yang dimaksud diantaranya, perayaan tahun baru Islam yang ada di bulan Muharram, peringatan maulid nama Muhammad SAW yang jatuh pada bulan Rabuil Awal, Isra Mi'raj yang jatuh pada bulan Rajab, Nuzulul qur'an dimana banyak pendapat menyakiki jatuh pada tanggal 17 Ramadhan, selain itu ada Idhul fitri dan Idhul adha.

a. Tahun Baru Islam

1 Muharram diperingati oleh umat Islam di dunia. Tanggal tersebut merupakan penanggalan baru dalam tahun baru Islam. Tahun baru Islam dimulai pada bulan Muharram. Jadi, lembaran amal dan perilaku manusia bagi umat Islam dimulai dari tanggal 1 Muharram.

b. Maulid Nabi Muhammad SAW

Maulid Nabi adalah hari kelahiran Nabi Muhammad. Perayaannya jatuh pada setiap tanggal 12 Rabiul Awal Tahun Hijriah. Sebenarnya, peringatan tentang hari lahirnya Nabi Muhammad ini disponsori oleh seorang pahlawan Islam yang bernama Shalahuddin Al-Ayyubi. Sekarang peringatan Maulid Nabi sudah membudaya dan dirayakan di mana-mana. Bahkan 
Eddy Saputra, Achmad Muhajir

bagi orang Islam Jawa perayaan ini ditambah dengan tradisi Muludan, dengan membuat kue-kue tertentu, dan sebagainya. ${ }^{1}$

c. Perayaan Isra Mi'raj

Isra' Mi'raj adalah hari raya untuk memperingiti peristiwa yang konon menjadi titik tolak diwajibkannya shalat lima waktu bagi umat Islam. Kewajiban tersebut diterima oleh Nabi Muhammad setelah menempuh perjalanan rohani yang amat intens, dari Masjid Haram ke Masjid Al-Aqsha, lalu dilanjutkan ke Sidratul Muntaha. Di situlah konon perintah shalat itu diterima. Mulanya shalat yang diwajibkan lima puluh kali dalam satu hari satu malam. Namun berkat negosiasi Nabi atas saran nabi sebelumnya, maka akhirnya tinggal hanya lima kali dalam satu hari satu malam. ${ }^{2}$

d. Peringatan malam Nuzulul Qur'an

Hari Nuzulul Qur'an adalah hari untuk memperingati turunnya Wahyu Al-Qur'an yang pertama kali, sebanyak lima ayat (Surah Al-Alaq ayat 1-5). Wahyu yang pertama kali turun itu jatuh pada tanggal 17 Ramadhan. Kemudian wahyu itu senantiasa turun seiring dengan persoalan-persoalan yang dihadapi oleh Nabi Muhammad. Solusi atas persoalan-persoalan yang muncul itu dinyatakan oleh ayat-ayat yang turun tersebut. ${ }^{3}$

Selain yang diatas masih ada Idul Fitri dan hari raya Qur'ban atau disebut juga Idul Adha. Kedua hari raya ini memiliki unsur syariat karena ada unsur ibadah didalamnya sekalipun hanya berhukum sunah, yakni menyangkut pelaksannan sholat di kedua hari raya tersebut. Berbeda dengan perayaan hari besar lainya di mana memeliki tujuan untuk memberikan edukasi kepada masyarakat bahwa telah terjadi peristiwa besar pada hari-hari tersebut. Contohnya seperti isra mi'raj sekalipun ada perintah sholat yang merupakan syariat islam akan tetapi dalam peringatan tersebuat hanya untuk mengingatkan pentingnya akan kewajiban sholat. Dimana masing-masing dari peringatan yang ada kaitan antara syariat dan bukan syariat akan dituangkan dalam bab pembahasan dan penelitian ini.

${ }^{1}$ Antonius Atosöhi Gea, dkk., Character Building III: Relasi dengan Tuhan, (Jakarta: PT. Elex Media Komputindo, 2004), h. 135-136

${ }^{2}$ Antonius Atosöhi Gea, dkk., Caracter Building III: Relasi dengan Tuhan, ...h. 136

${ }^{3}$ Antonius Atosöhi Gea, dkk., Caracter Building III: Relasi dengan Tuhan, ...h. 136 


\section{B. Metodelogi Penelitian}

Penelitian yang dilakukan adalah melalui pendekatan kualitatif deskriftif. Artinya data yang dikumpulkan bukan berupa angka-angka, melainkan data tersebut berasal dari naskah wawancara, catatan lapangan, pengamatan, dan catatan resmi lainya, sehingga yang menjadi tujuan dari penelitian kualitatif ini adalah ingin menggambarkan realita empirik dibalik fenomena yang terjadi didalamanya secara rinci dan tuntas. Oleh karena itu penggunaan pendekatan kualitatif dalam penelitian ini adalah dengan mencocokan antara realita empirik dengan teori yang berlaku dengan menggunakan metodologi kulaitatif deskriftif. ${ }^{4}$

Teknik pengumpulan data berdasarkan observasi yang terjadi di lapangan. agar peneliti benar-benar mendapatkan data yang sesungguhnya, sehingga data dapat di jelaskan dan disajikan merujuk kepada kejadian yang benar-benar terjadi di lapangan. Pengamatan terhadap objek baik secara langsung maupun tidak langsung sehingga data dapat dihimpun berdasarkan fakta yang ada dilapangan, dan bukan merupakan rekayasa. Artinya data yang tersaji benar-benar terjadi di lapangan.

1. Sumber data

Data yang di hasilkan dari beberapa informan yang terlibat aktif maupun pasif dalam kegiatan perayaan hari besar Islam

2. Teknik pengumpulan data

Metode yang digunakan melalui observasi secara langsung terhadap beberapa kegiatan perataan hari besar Islam, menghimpun data dari para informan dan orang-orang yang terlibat langsung dalam kegiatan tersebut

3. Analisis data

analisis data adalah proses mengorganisasikan dan mengurutkan data ke dalam pola, kategori, dan satu uraian dasar sehingga dapat ditemukan tema dan dapat dirumuskan hipotesis kerja seperti yang disarankan oleh data. Analisis data merupakan proses mengolah, memisahkan, mengelompokan, dan memadukan sejumlah data yang akan dikumpulkan dilapangan secara empiris menjadi sebuah kumpulan informasi ilmiah yang terstruktur dan sistematis kemudian siap dikemas menjadi laporan hasil penelitian.

${ }^{4}$ Moleong J lexy, Metode Penelitian Kualitatif, Edisi Revisi, Cet. ke 13 (Bandung: Remaja Rosdakarya, 2013), h. 45 
Eddy Saputra, Achmad Muhajir

Melalui wawancara peneliti dapat mengetahui secara langsung berdasarkan keterangan-keterangan melalui pertanyaan yang di ajukan kepada sumber yang akan di teliti, sehingga dapat memberikan keterangan atau jawaban terhadap pertanyan yang di ajukan. Analisis data dalam penelitian ini menggunakan model Miles and Huberman yaitu interaktif model. Secara umum Miles dan Huberman beranggapan bahwa analisis terdiri dari tiga alur kegiatan yang terjadi secara bersama yaitu, reduksi data, penyajian data, dan verifikasi data. $^{5}$

\section{Pembahasan}

\section{Pemahaman serta Nilai yang Didapat dari Peringatan Tahun Baru Islam.}

Tahun baru Islam adalah penanggalan tahun yang dimulai menggunakan perhitungan tahun hijriah, sementara tahun hijriah itu sendiri adalah tahun dimana rasullah Muhammad bin Abdillah melakukan perintah hijrah dari Mekkah menuju ke kota Madinah. Oleh sahabat Umar Ibnu Khatab perjalanan hijrah nabi inilah yang dijadikan awal dimulainya perhitungan tahun hijraih. Inti dari tahun baru Islam dalam rangka mengenang perjalanan rasullulah dalam menjalankan perintah Allah untuk berpindah dari kota Mekkah yang jahiliyah menuju kota Madinah dalam rangka melanjutkan risalah yang harus disampaikan pada umat manusia. Tahun hijriah sendiri memiliki dua belas bulan, ini sama dengan penanggalan yang menggunakan kalender masehi. Tahun hijriah dimulai dari bulam Muharram dan ditutup dengan bulan dzulhijah. Pada umumnya penanggalan pada kalender hijriah hanya sampai pada tangal 29 dan 30 sehingga memiliki selisih sekitar 14 hari dalam setahun terhadapa kelender masehi.

a. Bulam muharram dijadikan bulan pertama dalam kalender hijriah. Pilihan para shahabat menjadikan peristiwa hijrah nabi sebagai titik tolak awal perhitungan kalender Islam. Mengapa bukan berdasarkan tahun kelahiran Nabi saw.? Mengapa bukan berdasarkan tahun beliau diangkat menjadi Nabi? Mengapa bukan berdasarkan tahun Al-Qur'an turun pertama kali? Mengapa bukan berdasarkan tahun terjadinya perang Badar? Mengapa bukan berdasarkan tahun terjadinya pembebasan kota Mekkah?

5 Sugiono, Metode Penelitian Kuantitatif dan Kualitatif $R \& D$, (Bandung, Alfabeta, 2012), h. 
Mengapa bukan berdasarkan tahun terjadinya haji Wada' (perpisahan) dan mengapa bukan berdasarkan tahun meninggalnya Rasulullah saw.?. Jawabannya adalah karena peristiwa hijrah itu menjadi momentum di mana umat Islam secara resmi menjadi sebuah badan hukum yang berdaulat, diakui keberadaannya secara hukum international. Sejak peristiwa hijrah itulah umat Islam punya sistem undang-undang formal, punya pemerintahan resmi dan punya jati diri sebagai sebuah negara yang berdaulat. Sejak itu hukum Islam tegak dan legitimate, bukan aturan liar tanpa dasar hukum. Dan sejak itulah hukum qishash dan hudud seperti memotong tangan pencuri, merajam/mencambuk pezina, menyalib pembuat huru-hara dan sebagainya mulai berlaku. Dan sejak itulah umat Islam bisa duduk sejajar dengan negara/kerajaan lain dalam percaturan dunia international. $^{6}$

b. Makna Hijrah dan penguatan nilai keislaman.

Dalam perkembangan abad milenial kata hijrah sering digunakan para selebritis untuk menandai perubahan pada cara berpakaian. Kata hijrah akhir-akhir ini jadi tren di kalangan anak muda pegiat keagamaan untuk menunjukkan dirinya sudah tobat dan kembali ke jalan yang benar. Hijrah menjadi ungkapan yang menunjukkan dirinya insaf dari dunia kelam atau maksiat menuju kesadaran beragama. Sebenarnya kata hijrah mulai dikenal sejak zaman Nabi Ibrahim as. saat diucapkan bahwa saya berhijrah kepada Allah

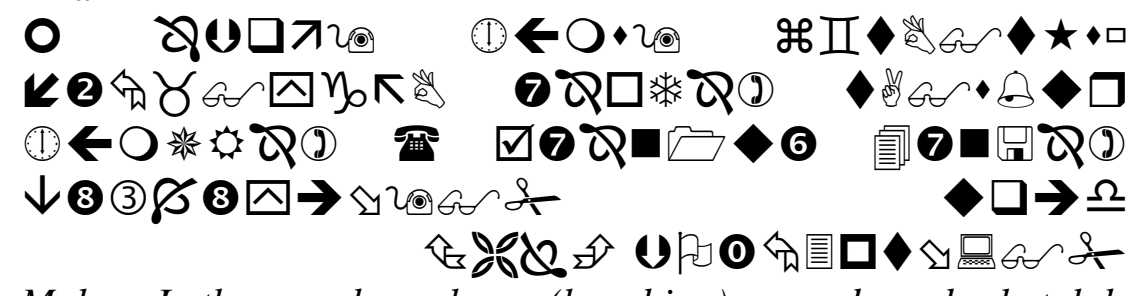

Maka Luth membenarkan (kenabian)nya. dan berkatalah Ibrahim: "Sesungguhnya aku akan berpindah ke (tempat yang diperintahkan) Tuhanku (kepadaku); Sesungguhnya Dialah yang Maha Perkasa lagi Maha Bijaksana. (QS. 29:26).

6 http://www.jadipintar.com,Pengertian-Dan-Sejarah-Tahun-Baru-HijriahSerta-Hukum-Merayakannya.html. Diakses pada tanggal 15 September 2019. 
Lima ribu tahun kemudian di zaman Nabi terakhir mulai dikenal lagi ungkapan hijrah saat sayyidina Ustman diizinkan oleh Nabi saw utk hijrah (pindah) ke Habasyah. Kemudian kata hijrah lebih populer saat peristiwa besar dan babak baru perjuangan Rasulullah saw ketika hijrah (pindah) dari Mekkah ke Madinah pada 622 Masehi. Di mana peritiwa hijrah itu oleh Sayyidina umar dijadikan nama tahun Islam atas saran sayyidina Ali dalam musyawarah para sahabat pada 14 Hijriah. Hijrah yang dilakukan Nabi saw seuntai antara fisik dan jiwanya. Ia hijrah dari Mekkah ke Madinah, hijjrah dari lingkungan yang mengusik ke lingkungan yang penuh keakraban sekaligus menujukkan hijrah yang utuh dalam keimanan. Menurut Al Qusyairi Hijrah itu ada dua: hijrah maknawi dan hissi atau biasa disebut hijrah zahir dan batin. Hijrah batin adalah pindah dari kekufurun menuju iman dan dari berserah diri kepada makhluk menuju penyerahan diri seutuhnya kepada Allah Swt. Adapun hijrah zahir adalah meninggalkan kemunkaran menuju keshalihan, dari pakaian terbuka menuju berhijab dan meninggalkan dunia kelam menuju hidayah. ${ }^{7}$ Kalaupun pada awalanya peringatan tahun baru islam kebanyakan tema yang dibahas seputar hijrahnya rasul dalam bentuk sebuah perjalanan fisik akan tetapi hijrah juga dapat dimaknai adannya perubahan dalam bentuk batin. Sehingga dapat diambil kesimpulan bahwa hijrah adalah sebuah perubahan dari kehidupan yang belum baik menuju ke yang lebih baik. Inilah benang merah yang diambil dari proses hijrah rosullulah, sehingga dengan perayaan tahun baru Islam, kita diingatkan kembali agar senantiasa melakukan kebaikan dalam berproses menjadikan pribadi yang lebih baik.

\section{Penguatan Nilai Keislaman Melalui Perayaan Maulid Nabi Muhammad Saw.}

Maulid Nabi Muhammad Saw bermakna (hari), tempat atau waktu kelahiran Nabi yakni peringatan hari lahir Nabi Muhammad Saw. Secara terminologi, Maulid Nabi adalah sebua upacara keagamaan yang diadakan kaum muslimin untuk memperingati kelahiran Rasulullah Saw. Hal itu diadakan dengan harapan

7 Cholil Nafis, Artikel ini telah tayang di Tribunnews.com dengan judul Mengurai Makna Hijrah, ttp://www.tribunnews.com/tribunners/2017/09/20/menguraimakna-hijrah. Diakses pada tanggal 15 September 2019. 
menumbuhkan rasa cinta pada Rasululllah Saw. Perayaan Maulid Nabi merupakan tradisi yang berkembang di masyarakat Islam jauh setelah Nabi Muhammad Saw wafat. Perayaan Maulid Nabi diperkirakan pertama kali diperkenalkan oleh Abu Said al-Qakburi, seorang gubernur Irbil, di Irak, pada masa pemerintahan Sultan Salahuddin al-Ayyubi (1138 H-1193 M). Adapula yang berpendapat bahwa idenya sendiri justru berasal dari Sultan Salahuddin sendiri. Tujuannya adalah untuk membangkitkan kecintaan kepada Nabi Muhammad Saw, serta meningkatkan semangat juang kaum muslimin saat itu, yang sedang terlibat dalam Perang Salib melawan pasukan kristen Eropa dalam upaya memperebutkan kota Yerusalem.

Fakta yang sesungguhnya dari kehidupan Rasulullah Saw menegaskan bahwa tidak ada riwayat yang menyebutkan beliau pada tiap ulang tahun kelahirannya melakukan ritual tertentu. Bahkan para shahabat beliau pun tidak pernah kita baca dalam sejarah pernah mengadakan ihtifal (seremoni) secara khusus setiap tahun untuk mewujudkan kegembiraan karena memperingati kelahiran Nabi Saw bahkan upacara secara khusus untuk merayakan ritual maulid Nabi Saw juga tidak pernah dilakukan dari generasi tabi'in hingga generasi salaf selanjutnya. Perayaan seperti ini secara fakta memang tidak pernah diajarkan, tidak pernah dicontohkan dan juga tidak pernah dianjurkan oleh Rasulullah Saw, para shahabat bahkan para ulama salaf di masa selanjutnya.

Perayaan maulid Nabi Saw secara khusus baru dilakukan di kemudian hari, dan ada banyak versi tentang siapa yang memulai tradisi ini. Sebagian mengatakan bahwa Shalahuddin al-Ayyubi yang mula-mula melakukannya, sebagai reaksi atas perayaan natal umat Nasrani. Karena saat itu di Palestina, umat Islam dan Nasrani hidup berdampingan. Sehingga terjadi interaksi yang majemuk dan melahirkan berbagai pengaruh satu sama lain. Versi lain menyatakan bahwa perayaan maulid ini dimulai pada masa dinasti Daulah Fatimiyyah di Mesir pada akhir abad keempat hijriyah. Hal itu seperti yang ditulis pada kitab al-A'yad wa atsâruha ala al-Muslimîn oleh Sulaiman bin Salim as-Suhaimi. Disebutkan bahwa para khalifah Bani Fatimiyyah mengadakan perayaan-perayaan setiap tahunnya, di antaranya adalah perayaan tahun baru, Asyura, maulid Nabi Saw bahkan termasuk maulid Ali bin Abi Thalib, maulid Hasan dan Husein serta maulid Fatimah dan lain-lainnya. Versi 
lainnya lagi menyebutkan bahwa perayaan maulid dimulai tahun 604 H oleh Malik Mudaffar Abu Sa ${ }^{e i} i d$ Kukburi. ${ }^{8}$

Masyarakat muslim di Indonesia umumnya menyambut maulid Nabi dengan mengadakan perayaan-perayaan keagamaan, seperti: pembacaan shalawat Nabi, pembacaan syair Barzanji dan pengajian. Menurut penanggalan Jawa bulan Rabiul Awal disebut bulan Mulud. Dapat dipahami bahwa tradisi keagaman perayaan maulid merupakan salah satu sarana penyebaran Islam di Indonesia, Islam tidak mungkin dapat tersebar dan diterima masyarakat luas di Indonesia, jika saja proses penyebarannya tidak melibatkan tradisi keagamaan. Yang jelas terdapat fakta yang kuat bahwa tradisi perayaan maulid merupakan salah satu ciri kaum muslim tradisional di Indonesia. ${ }^{9}$

Hal itu dilakukan karena dasar pandangan ahlus sunnah wal jama'ah, corak Islam yang mendominasi warna Islam Indonesia, lebih fleksibel dan toleran dibanding dengan kelompok lain. Mempertahankan tradisi menjadi sangat penting maknanya dalam kehidupan keagamaan mereka, berdasarkan pada kaidah ushuliyah, al-muhafadzah li al qadim al-shalih, wa al-ahdza min jadid al ashlah. Inilah kemudian dalam wacana keilmuan disebut sebagai Islam Tradisional. Justru karena kemampuan dalam menyesuaikan ajaran Islam dengan tradisi yang telah mengakar dalam masyarakat inilah, maka kelompok tradisional Islam berhasil menggalang simpati dari berbagai pihak yang menjadi kekuatan pedukung. Rozikin Daman memandang bahwa hal inilah yang mendorong timbulnya kelompok tradisionalisme dan sekaligus menjadi salah satu faktor pendorong bagi tumbuhnya gerakan tradisionalisme Islam. ${ }^{10}$

a. Maulid Nabi Muhammad Saw Korelasinya dalam Meningkatkan Akhlak.

Memaknai maulid tidak hanya sekedar membedah sejarah nabi Muhammad saw dari kelahiran sampai wafatnya beliau. Melalui maulid setidaknya kita bisa mengetahui bagaimana beliau menyampaikan risalah Allah swt yang telah di amanatkan agar di

${ }^{8}$ Nico Kaptein, Perayaan Hari Sejarah Lahir Nabi Muhammad Saw, Asal Usul

Sampai Abad ke 10/16, terj. Lillian D. Tedjasudhana, (Jakarta: INIS, 1994), h. 10

${ }^{9}$ Machasin, "Dibaan/Barjanjen dan Identitas Keagamaan Umat" dalam jurnal Theologia, Fak Ushuluddin IAIN Walisongo, vol 12, no 1 Pebruari, 2001, h. 23

10 Rozikin Daman, Membidik NU:Dilema Percaturan Politik NU Pasca Khittah, (Gama Media, Yogyakarta, 2001), h. 35. 
sampaikan pada jutaan umat manusia. Kehidupan jahiliyah yang ada pada masa itu menandakan minimya perangai manusia dan jauh dari kata kemanusian. Para prinsip yang utaman dalam ajaran Islam memang yang diutmakan adalah akhlak sebagai mana tujuan utama Rasulullah diutus hanya untuk menyempurnakan akhlak sebagaimana yang tertera dalam hadits riwayat al-Baihaqi.

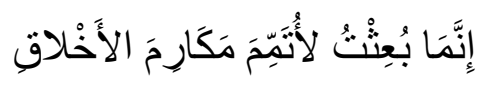

"Sesungguhnya aku diutus hanya untuk menyempurnakan keshalihan akhlak." (HR. Al-Baihaqi).

Dan ayat al-Qur'an:

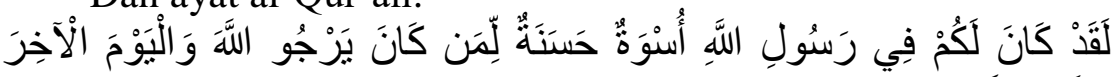

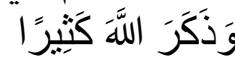

"Sesungguhnya telah ada pada (diri) Rasulullah itu suri teladan yang baik bagimu (yaitu) bagi orang yang mengharap (rahmat) Allah dan (kedatangan) hari kiamat dan dia banyak menyebut Allah". (QS Al-Ahzab: 21).

Tujuan dari maulid diselenggaragakan agar generasi muda mengetahui bagaimana Rasulullah berjuang menyampaikan syiar Islam melalui al-akhlak al-karimah, Islam yang ramah, Islam yang penuh keterbukaan, serta Islam toleran. Muncul berbagai aksi radikalisme dan terorisme yang lekat dengan simbol-simbol Islam membuat sebagian besar orang yang belum mengenal Islam memiliki stigma negatif terhadap Islam. Melalui maulid Rasulullah ingin menegaskan bahwa Islam dibangun atas dasar al-akhlak al-karimah bukan hanya sekedar mengedepankan simbol semata. Simbol penting sebagai identitas akan tetapi akhlaklah identitas sesungguhnya dari ajaran Islam. Perayaan maulid bukan hanya sekedar seremoni akan tetapi lebih kepada meningatkan serta membangkitkan kesadaran kita akan tanggung jawab kita sebagai seorang hamba Allah. Terdapat kewajiban dalam diri kita untuk tetap menampilkan nilai-nilai keislaman melalui al-akhlak al-karimah yang telah dicontohkan pada diri Rasulullah.

b. Hikmah Maulid di era modern. 
Meneladani perilaku dan perbuatan mulia Rasulullah Saw. Tanamkan keteladanan Rasul ini dalam keseharian kita, mulai hal terkecil, hingga paling besar, mulai kehidupan duniawi, hingga urusan akhirat. Tanamkan pula keteladanan terhadap Rasul ini pada putra-putri kita, melalui kisah-kisah sebelum tidur misalnya. Sehingga mereka tidak menjadi pemuja dan pengidola figur publik berakhlak rusak yang mereka tonton melalui acara televise. Akhlak Rasulullah adalah cerminan al-Qur'an, beliau sosok sempurna yang hadir ditengah-tengah umat manusia, menyampaikan kabar gembira membawa penerangan dalam kegelapan melalui cahaya Islam. Rasullullah juga memeliki sifat yang begitu melekat pada diri beliau yaitu, sidiq, amanah, tablig dan fathanah.

Peringatan Maulid Nabi SAW mendorong orang untuk bersholawat pada nabi sholawat adalah cerminan secara lisan bentuk kecintaan pada nabi, dimana yang paling utamanya adalah dengan mengimplementasikan sholawat dalam bentuk yang diterapkan dikehidupan sehari-hari.

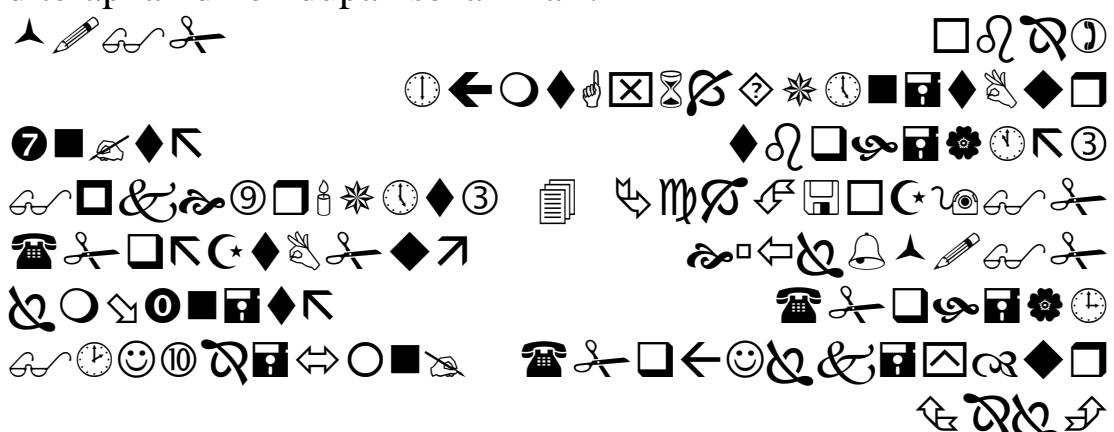

"Sesungguhnya Allah dan malaikat-malaikat-Nya bershalawat untuk Nabi. Hai orang-orang yang beriman, bershalawatlah kamu untuk Nabi dan ucapkanlah salam penghormatan kepadanya( Al ahzab:56)

\section{Perayaan Isra mi'raj dan Nilai Keislaman}

Isra Mi'raj merupakan perjalanan spiritual Nabi Muhammad SAW suatu malam sekian abad yang lalu yang fantastis dan terkesan dramatis. Ada dua tahap perjalanan, yaitu tahap horizontal dari Masjidil Haram di Makkah ke Masjidil Aqsa di Palestina. Tahap kedua adalah tahap vertikal dari Masjidil Aqsa ke Sidratul Muntaha di langit ke tujuh. Sebagaimana Allah jelaskan dalam ayat Qur'an: 


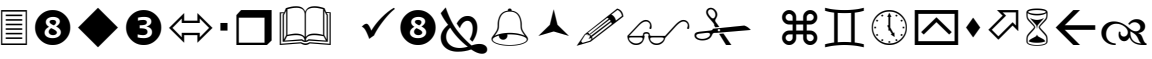

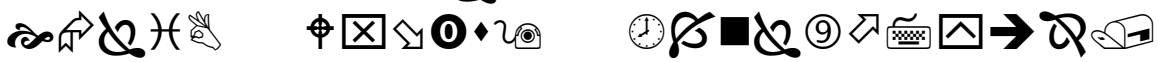

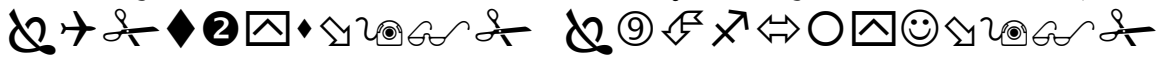

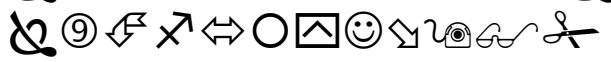
8d2 1 a f of (1) 今ा II है

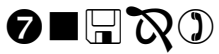

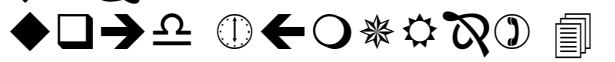
(32) (1)

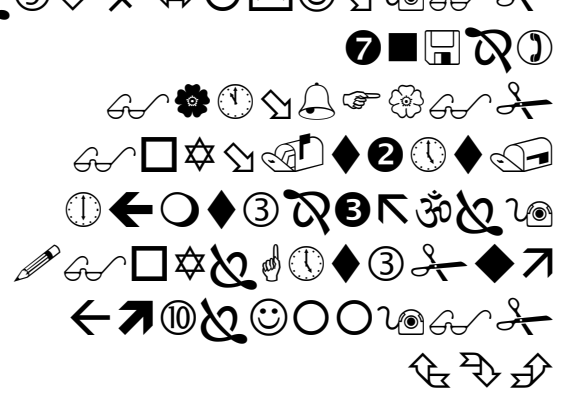

"Maha suci Allah, yang telah memperjalankan hamba-Nya pada suatu malam dari Al Masjidil Haram ke Al Masjidil Aqsha yang telah Kami berkahi sekelilingnya agar Kami perlihatkan kepadanya sebagian dari tanda-tanda (kebesaran) kami. Sesungguhnya Dia adalah Maha mendengar lagi Maha mengetahui.(QS. Al Isra:1)

Perjalanan Isra Mi'raj dalam rangka menerima perintah shalat dari Allah, tanpa melalui perantara. Hal ini menunjukkan pentingnya shalat bagi kaum Muslimin. Shalat yang dilakukan akan dapat mengubah kehidupan seseorang menjadi lebih bermakna. Sholat merupakan rukun dalam islam, sehingga harus dikerjakan sebagai orang yang mukallaf (secara ilmu fiqh adalah orang yang sudah memiliki kewajiban menjalankan hukum islam apabila ditinggalkan maka orang tersebut berdosa). Penekanan pada perintah shalat inilah esensi dari perayaan isra mi'raj. Dalam fakta kehidupan masih banyak orang yang mengabaikan sholat sekalipun adzhan selalu berkumandang disetiap waktu sholat tiba tidak cukup untuk membuat kebanyakan dari kita sadar pentingnya sholat.

Shalat merupakan bentuk komunikasi kita pada sang khalik semakin intens komunikasi berjalan maka semakin baik hubungan itu terjadi. Sholat juga merupakan bentuk keaktifan kita dalam menghambakan diri kepada Allah SWT. Dengan sholat Allah menjamin manusia yang melaksanakan terhindar dari perbuatan keji dan munkar

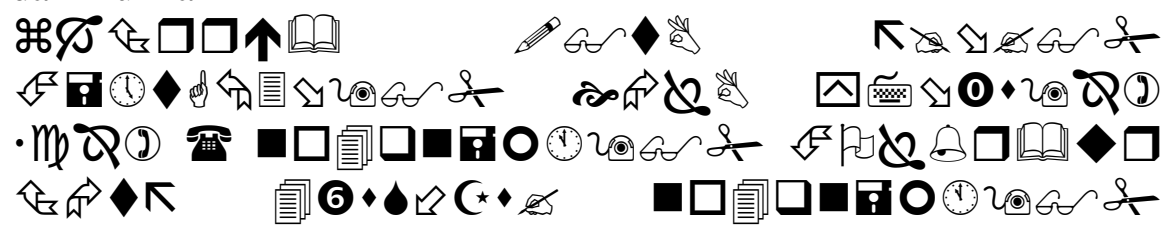




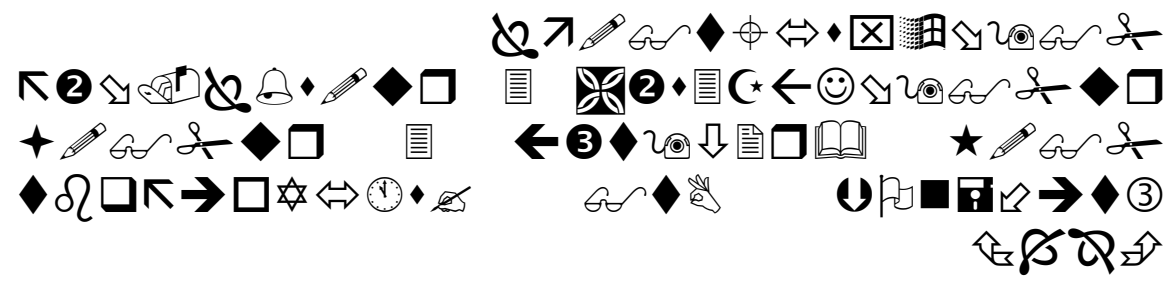

Bacalah apa yang telah diwahyukan kepadamu, Yaitu Al kitab (Al Quran) dan dirikanlah shalat. Sesungguhnya shalat itu mencegah dari (perbuatan- perbuatan) keji dan mungkar. dan Sesungguhnya mengingat Allah (shalat) adalah lebih besar (keutamaannya dari ibadat-ibadat yang lain). dan Allah mengetahui apa yang kamu kerjakan. (QS. Al ankabut: 45)

Ayat ini menggunakan redaksi mendirikan sholat bukan mengerjakan. Maksudnya adalah agar sholat yang dikerajakan mampu memberi dampak yang positif terhadap perubahan hidup manusia, tidak sekedar ritual yang cenderung hanya menggugurkan kewajian semata, sehinga sholat mampu menjadi perisai atau pelindung bagi siapa saja yang menjalankan dari perbuatan keji dan munkar. Disinilah esensi peringatan isra mi'raj dengan menjelaskan sekaligus mengingatkan kembali makna sholat yang terkandung dalam perjalannya sehingga kita kembali disadarkan akan kewajiban kita sebagai seorang hamba agar senantiasa beribadah kepada Allah Swt.

\section{Peringatan Nuzulul Qur'an dan Nilai Keislaman}

Al-Qur'an yang diturunkan dalam masa 23 tahun, atau tepatnya, dua puluh dua tahun dua bulan dua puluh dua hari, yang terdiri dari 114 surat, 30 juz, dan susunanny ditentukan oleh Allah dengan cara tawqifi, tidak mengggunakan metode-metode sebagaimana metodemetode penyusunan buku-buku ilmiah. Bukubuku ilmiah yang membahas satu masalah, selalu menggunakan satu metode tertentu dan dibagi dalam bab-bab dan pasal pasal. Metode ini tidak terdapat di dalam al-Qur'an, yang di dalamnya banyak persoalan induk silih berganti diterangkan.

Al-Qur'an merupakan petunjuk bagi manusia menyangkut tuntunan yang berkaitan dengan aqidah, dan penjelasan mengenai petunjuk itu dalam hal rincian syariat, dengan diturunkannya alQur'an pada bulan ramadhan, mengisyaratkan bahwa sangat

${ }^{11}$ M. Quraish Shihab, Membumikan al Qur'an: Fungsi peran wahyu dalam kehidupan masyarakat, (Bandung: Mizan, 2013), Edisi ke-2, cet. ke 1, h. 23 
dianjurkan untuk membaca dan mempelajari al-Qur'an selama bulan ramadhan, dan yang mempelajarinya diharapkan memperoleh petunjuk serta memahami dan menerapkannya penjelasanpenjelasannya. Karena dengan membaca al-Qur'an ketika itu bahwa yang bersangkutan menyiapkan wadah hatinya untuk menerima petunjuk Ilahi berkat makanan ruhani-bukan jasmani-yang memenuhi kalbunya. Bahkan jiwanya akan semakin cerah, pikirannya begitu jernih, sehingga ia akan memperoleh kemampuan untuk membedakan antara yang haq dan yang bathil. ${ }^{12}$

Dalam peringatan nuzulul Qur'an kita kembali diingatkan bahwa wahyu Allah yang diturunkan melalui perantara malaikat Jibril kepada Nabi Muhammad SAWdimana banyak sekali makna yang terkandung didalamnya. Wahyu yang pertama yang diterima adalah surat $\mathrm{Al}$-Alaq ayat $1-5$ yang berbunyi "Iqra" yang berarti bacalah. Ini bisa dimaknai dengan membaca, maka akan terbuka cakrawala manusia sehingga bijak dalam berfikir dan berbuat kemudian menghadirkan sebuah kesadaran bahwa manusia di ciptakan untuk beribah kepada Allah Swt. Disisi lain Allah juga menjelskan tujuan kenama Al-Qur'an di turunkan dalam surat AlBaqarah ayat 185 .

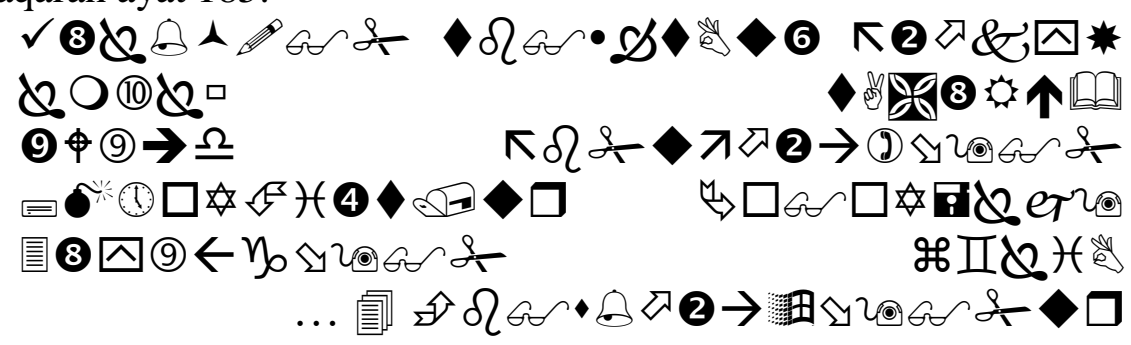

"Beberapa hari yang ditentukan itu ialah) bulan Ramadhan, bulan yang di dalamnya diturunkan (permulaan) Al Quran sebagai petunjuk bagi manusia dan penjelasan-penjelasan mengenai petunjuk itu dan pembeda (antara yang hak dan yang bathil).

Ayat menjelaskan ada tiga tujuan al qur'an kenapa diturunkan yaitu sebagai petunjuk manusia, sebagai penjelas serta sebagai pembeda antara yang baik dan yang buruk. Sebagai petunjuk al qur'an akan mengarahkan perjalanan hidup manusia sesuai kodrat

${ }^{12}$ M. Quraish Shihab, Wawasan al Qur'an: Tafsir maudhu'i atas pelbagai persoalan umat, (Bandung: Mizan, 2005), cet. ke XV, h. 48 
yang diciptakan yaitu beribadah. Dengan beribadah hidup manusia dapat lebih terarah sehingga memiliki dampak posisif dalam kehidupannya baik dunia dan akirat.

Sebagai penjelas al-Qur'an adalah merupakan undang-undang yang menginformasikan apa saja yang boleh manusia lakukan dan yang tidak boleh dilakukan, diadalamnya ada perintah dan ada laranagan. Ada halal dan nada yang diharamkan. Kemudian sebagai pembeda antar yang hak dan bathil. Jelas ada perbedaan terhadap orang-orang yang menjalankan perintah yang ada dalam al-Qur'an. Orang yang menjalankan akan lebih mawas diri dan hati-hati dari perbuatan dosa sehingga dapat memberi dampak positif bagi dirinya dan orang lain, dan orang yang jauh dari al qur'an cenderung banyak perintahnya yang dilanggar yang berakibat buruk pada dirinya dan juga orang lain.

Peringatan malam nuzulul Qur'an adalah sebuah pembelajaran bagi kita agara kita kembali berpegang teguh pada ajaran-ajaran yang terkandung di dalamnya serta membangkitkan kembali pada sebuah kesadaran akan pentingnya sebuah aturan bagi manusia dalam rangka menjalankan kehidupan di dunia dan di akhirat.

\section{Kesimpulan}

Perayaran hari besar Islam masih perlu dilestarikan dan dipertahankan, ini dapat dijadikan media untuk mengingatkan kembali bahwa ada nilai-nilai keislaman yang dapat dibangun di tengah masyarakat. Pendidikan keislaman tidak hanya bersifat formil yang selalu berpatokan pada bangku sekolah akan tetapi bisa dibangun dari sisi lain yaitu yang berupa pendidikan non formal, dimana salah satunya yaitu dengan mempertahankan perayaan hari besar Islam di tengah-tengah masyarakat. Peryaraan hari besar Islam juga dapat menjadi cara untuk meningkatkan hubungan kemasyarakatan tanpa ada sekat-sekat jabatan golongan ataupun kelompok. Stratifikasi yang sering di kembangkan oleh sebagian orang akan lebur menjadi satu, karena perayaraan ini selalu diadakan dalam dimensi kelompok yang lebih besar sehingga tidak terlihat ada perbedaaan antara satu dengan yang lainnya. Islam adalah agama yang rahmatan lilalamin, sehingga dalam pelaksanaannya harus dengan kelembutan dan kasih sayang. Islam harus menampilkan wajah yang ramah, shalat yang dibarengi alakhlak al-karimah harus menjadi identitas bagi seorang muslim serta Al-Qur'an harus diimplementasikan dalam kehidupan sehari-hari, ini semua dapat disampaikan melalui perayaan hari besar Islam sebagai 
upaya dalam mempertahankan identitas sebagai seorang muslim yang berakhlak baik kepada siapapun.

\section{Daftar Pustaka}

Daman, Rozikin, Membidik NU:Dilema Percaturan Politik NU Pasca Khittah, Gama Media, Yogyakarta, 2001

Gea, Antonius Atosöhi, dkk., Character Building III: Relasi dengan Tuhan, Jakarta: PT. Elex Media Komputindo, 2004

http://www.jadipintar.com,Pengertian-Dan-Sejarah-Tahun-BaruHijriah-Serta-Hukum-Merayakannya.html. Diakses pada tanggal 15 September 2019.

Kaptein, Nico, Perayaan Hari Sejarah Lahir Nabi Muhammad Saw, Asal Usul Sampai Abad ke 10/16, terj. Lillian D. Tedjasudhana, Jakarta: INIS, 1994

Lexy, Moleong J, Metode Penelitian Kualitatif, Edisi Revisi, Cet. ke 13 Bandung: Remaja Rosdakarya, 2013

Machasin, "Dibaan/Barjanjen dan Identitas Keagamaan Umat" dalam jurnal Theologia, Fak Ushuluddin IAIN Walisongo, vol 12, no 1 Pebruari, 2001

Nafis, Cholil, Artikel ini telah tayang di Tribunnews.com dengan judul Mengurai Makna

Hijrah, ttp://www.tribunnews.com/tribunners/2017/09/20/menguraimakna-hijrah. Diakses pada tanggal 15 September 2019.

Shihab, M. Quraish, Membumikan al Qur'an: Fungsi peran wahyu dalam kehidupan masyarakat, Bandung: Mizan, 2013 - Wawasan al Qur'an: Tafsir maudhu'i atas pelbagai persoalan umat, Bandung: Mizan, 2005

Sugiono, Metode Penelitian Kuantitatif dan Kualitatif $R \& D$, Bandung, Alfabeta, 2012 